\title{
ATTITUDES OF PRESENT GENERATION TOWARDS MARRIAGE: A SURVEY OF MARRIAGEABLE COLLEGE STUDENTS
}

\author{
Pralhad Adhikari*
}

\begin{abstract}
Marriage is an important personal and social affair. A qualitative research was conducted to study attitude of present generation towards marriage.Sample size was 51. There was the use of triangulation of data and methods. When the study was carried out first, the qualitative data were collected by in-depth interview and analyzed manually in the interpretive-thematic analysis framework. Data saturated after 16 persons of marriageable age, those between 18 and 35, were interviewed.Some were interviewed twice or thrice. After five years, survey questionnaire was given to 35 individuals of marriageable age who were between 19 and 24. It consisted of five open-ended questions.Both samples comprised of the men and women living in Kathmandu valley at the time of research. Non-random convenience sampling method was used. Some themes were identified on why people marry.For current generation, marriage is needed for support, company, fulfilment of sex motive and conscious or unconscious social pressure. It was found that present generation perceives that parent generation married to continue customs, to obey parental orders and to settle permanently meaning to start a new family by bearing children.Race continuity is the common theme seen on both generations. The intention, beliefs and feelings of participants about marriage have been inquired to know the conative, cognitive and affective components of attitude.
\end{abstract}

Key words: Attitude, conformity, marriage, present generation, parent generation, race continuity, support

\section{INTRODUCTION AND OBJECTIVE}

The state of being united to a person of the opposite sex as wife or husband in a relationship recognized by law or society has been defined as marriage. Marriage is a popular ritual in all cultures and is attributed to private functions such as sexual gratifications and social functions like division of

* Mr Adhikari is Assistant Professor in Department of Psychology and Philosophy, Trichandra Multiple Campus, TU. 
168 ATTITUDES OF PRESENT GENERATION TOWARDS MARRIAGE ...

labor between genders. Marriage primarily serves for reproduction, care of children and continuation of race (Encyclopedia, 2015). It is not only culturally significant thing but also it is evolutionarily significant.Seligman (2004) invalidates the view of many social scientists that marriage is a socially concocted institution and asserts marriage is invented by evolution but culture. Marriage is a big transition in life (Fricke, Arland, \& Dahal, 1998).

Shrestha (1987) says that marriage is sanctioned by Vedic system as essential spiritual ritual. In Nepal, marriage is religiously sanctioned. The bridegroom leads a procession of kith and kin to go to bride's house to feast and put vermillion powder on her parting and finally bring her home. There are many gala, music and festivities accompanied. The economic aspect of marriage can be too devastating. The most admired nuptials are those in which a dowry is granted by the bride's family (Prindle, 1978). In Hindu religion, it's believed the donation of maid (daughter) is the best of all alms. So early marriage is rampant. The beginning of menarche among females signals that they will be ready for marriage and hence giving birth of child (Aryal, 2011). Marriage means living together, having sexual relation with a partner, sharing economic resources and being recognized as parents of their children(Skolnick, 2008). In past, the marriage was arranged; the average age was around or less than 20 . The mass media aired 'the matrimony, beyond 20' campaign in Nepal. The present generation of marriageable age might not marry for same reasons and by same way. The age of marriage has shifted too. The jobs and education among women is responsible for change in dynamics of marriage (The Economist, 2011). Age of marriage increases with educational attainment(Coltabiano \& Castiglioni, 2008) Ahearn (2002) points out that even literacy is enough to change the way the people think about love and marriage.

Nepal is notorious for child marriage (Doskoch, 2013). Nepal is the country with early marriage pattern (Thapa \& Padhye, 2001; Thapa \& Retherford, 1976). Still, 'marriageable age' has been taken starting from 18 (which is legally sanctioned (Doskoch, 2013)) to 40, over which a marriage would be considered 'very late marriage'. With the advancement of time (or generations), society changes in various ways. Attitude change regarding marriage is obvious too. Attitudes can be influenced by and can influence beliefs, affect, and behavior in relation to the attitude object (Matsumoto, 2009). 
From psychological standpoint, this research is a pioneer in study of attitude about marriage. The attitude of present generation towards marriage has been contrasted with their perception of why their parents married.

\section{REVIEW OF LITERATURE}

The pattern of marriage is changing in the society. The age is rising and the causes of marriage are evolving too. The attitude towards marriage is changing. Tuladhar (1998) mentions that mean age of marriage has increased from 15.4 in 1961 to 18.1 in 1991 making a difference of 2.7 years. Quoting Poudel (1992), Tuladhar (1998) says that the mean age of marriage among literate women was 17.1 year while that among the illiterate women was 12.8 years. She has also concluded that age at marriage increases with higher level of educational attainment. Aryal (2007) has found out median age of marriage for females is 18 years. In Palpa and Rupandehi districts Aryal (2011) found out that median age at marriage was 16.8 years while age at first-birth was 19 years (Aryal, 2007). Median age at marriage is about 16 years for uneducated females and 19 years for educated females. According to Yabiku (2004), topographic and social transformation of a place can engage young adulthood in various activities and delay marriage. For men, employment is supposed to hasten marriage. Women who are illiterate have lowest age at marriage (17.6) while with the educated the highest (21.1). Occupational factors are less effective to raise age at marriage than the educational factors. Factors such as matrilocal post- marital residence, choice of spouse, less emphasis on a bride's virginity, equal rights to divorce for both spouses, village endogamy, and absence of dowry (Niraula \& Morgan, 1996) would give higher status for women and it would up the age of marriage. To reduce the burden of dowry, Magars involve in capture and love marriage rather than arranged one.

Tuladhar (1998) Mentions that in Nepal almost all births occur within marriage, and out of wedlock marriages are not indorsed by the society.In various parts of country, before 50 years, there was polyandry and extended family. Girls could go to the boy's house to beget children without marrying. Still the child would be illegitimate (Chalaune, 2009; Shreth, 1987). Rajbanshi community gives preference to the arranged marriage (Shrestha, 2009). A matchmaker initiates the marriage proposal 


\section{ATTITUDES OF PRESENT GENERATION TOWARDS MARRIAGE ...}

and the priest performs the rituals of marriage. This is how all of Nepal generally marries. Young age at marriage in Nepal is related to the practice of arranged marriages, where relationships and compromises between families prevail over individual wants (Coltabiano \& Castiglioni, 2008). Family is the most important unit of the social structure and marriage is its foundation (Amatya, 2005).

In suburban and urban areas, dating is so commonplace. Dating is still seen as taboo in rural areas. Literate women may write love letters rather than go for date before they elope (Ahearn, 2008). However, the marriage is given social acceptance afterwards. Marriage has historically united families in lasting networks of support involving the exchange of goods, labor, and services (Fricke, 1998).

Marriage is the most important personal relationship for South Asians. Even affected by western influence on technology, they tend to maintain traditional expectations regarding family life (Ahmad \& Reid, 2008). The situation outside South Asia is different. All over Asia, marriage pattern and family life are changing. Young people are waiting to marry late(Choe, Westley, \& Retherford, 2002). Marriage was nearly universal in the past in Asian societies (Thapa \& Padhye, 2001). In Nepal also, marriage is almost universal (Coltabiano \& Castiglioni, 2008). Even among 15-19year-old women, 62 percent are married, and by ages 20-24, 92 percent are (Lengthy Breastfeeding Is the Primary Fertility-Reducing Factor in Nepal, 1987). Age of marriage increases with educational attainment (Coltabiano \& Castiglioni, 2008). Increased schooling gave girls courage to resist early marriage (Mishra, 2012). Over the past decades, the proportion of women remaining single in 30s and 40s has tremendously grown in East and South-east Asian societies (Jones, 2003). As many men and women of marriageable age started remaining single, the government had to use social media like Facebook to promote marriage in efforts to reverse low birth rates in Singapore (Lee, 2012). Even the people from the lowest educational background show nontraditional attitudes towards marriage and family, post-revolution, in Iran (Tashakori \& Thompson, 1988). According to Kirkpatrick (1936), 1 in 3 persons of younger generation think that sex before marriage is interesting. Higgins, Zheng, Liu, and Sun (2002) say that traditional values in mate-selection preferences persist more in China than in the United Kingdom; the Chinese are still traditional even though 
there have been a lot of developments in the recent decades. The attitude towards gay marriage has significantly liberalized (Baunach, 2011). Nonmarriage is becoming much more common.Singleness as a life-style is being recognized (Freedman, 1982). People no longer disapprove of not getting married or late marriage. In East Asian countries, the late marriage and non-marriage is still rising (Jones, 2012). The mean age of wedlock is now 29-30 for women, 31-33 for men in Japan, Taiwan and the region (Enyclopeodia, 2017). More than half of Swedish women bore children out of marriage. In the urban areas of South Asia including Nepal's, the attitude and trend towards marriage are changing. The younger generation are not in a great pressure to marry from their parents (Freedman, 1982).

The men and women of marriageable age in Kathmandu are marrying in their late twenties or early thirties. The increased autonomy of young people in discretion to decide on ownmarriage is catalyzing social changes (Fricke, 1998). The reasons why they marry differ from their parents'. Intercaste marriage is gradually increasing (Duberman \& Azumi, 1975).The polyandry like in Gurungs of upper Mustang (Gurung, 2012) and polygyny of many tribal classes is dismissing as they connect to the outer world after political changes and mobile phone revolution. The educated young adults remain busy in pursuing career as well as education, and marry late. When the parental authority decreases, the children may not follow the parental marriage patterns (Yabiku, 2004). Education, occupation and age at menarche are the most powerful factors in deciding the timing of first marriage in Nepal (Aryal, 2007).Many factors like age at menarche, dowry and cost of marriage and cross-border marriage migration are found to affect age at marriage of girls in the Terai region (Sah, 2008).

Even though the attitude change in marriage has come, it continues to be valued by the younger generation (Freedman, 1982). Marriage still tickles their fancies. Dating, courtship and engagement is gradually diffusing to younger generation (Podmore \& Chaney, 1972). Romantic love is in the trend to institutionalize as base to marriage but romantic love was never a reason to marry in past. Traditional norms about universal marriage and childbearing are demolishing in the developed nation (Gubernskaya, 2010) and the respective governments, so worried, are launching programs to regress the trend. In Nepal, education, job opportunities, foreign cultural influence, the internet boom, Facebook spread and mobile revolution have 
contributed to the attitude change in many social phenomena and structures including marriage. The aims of this study were to peer into the cognitive, conative and affective components of attitude of present generation towards marriage and also to slightly contrast them with participants' perception on why their parents married.

\section{METHOD}

There is the use of triangulation of method and data. When the data were first collected in 2012, the qualitative data were collected by in-depth interview and analyzed manually in the interpretive-thematic analysis framework. For data collection, each participant was approached in a friendly and polite manner. A rapport was built. They were told about researcher's purpose. Informed consent was taken. They were interviewed and parted with a refreshment and contact details for possible follow-up interviews. The interview was unstructured. It consisted of questions like When is the appropriate age for marriage?, What are your feelings about marriage?, What is your plan for marriage? or Why did you get married?, and Why do you think your parents married? When the data were collected in 2017 for the second time with the purpose of triangulation, they were collected by survey method using questionnaire consisting of five openended questions. The questionnaire collected some demographic variables like age, gender and ethnicity. It consisted of following questions:

- Why do you think people marry?

- What are your feelings about marriage?

- What are your thoughts about marriage?

- What is your plan for marriage? / Why did you marry?

- Why did your parents marry?

The participants were first interviewed about their attitude on marriage. It was carried out in 16 persons ( 7 male and 9 female) of marriageable age. Again 35 participants were surveyed by convenience sampling. There were 22 female and 13 male studying Bachelor of Arts in Social Work between ages 19 and 24. Present generation is operationally defined as people of marriageable age i.e. 18-35 years and generation of their parents has been defined as parent generation. The analysis of data went hand in hand. As theoretical saturation was gotten after $16^{\text {th }}$ interview, it was stopped. Some participants had to be interviewed two or three times. 
The sample comprised of men and women of marriageable age living in Kathmandu valley. They were interviewed when they visited Kirtipur. Some were married and some were yet to marry. The sampling method used was non-random and convenient. The reasons of parents' marriage were also solicited from the children. The survey research was done in a college at Boudha of Kathmandu and participants were living in various parts of Kathmandu. They represented various districts like Kalikot, Sankhuwasabha, Sindupalchok and Kathmandu. According to ABC model of attitude in the social psychology, A stands for affect, B stands for behavior and $\mathrm{C}$ stands for the cognition. So, attitude change entails conversion in all these three components.Attitude is solely dealt by social psychology as asophisticated mental state involving beliefs, feelings, and personalities to act in certain ways. It has evaluative characteristics. It is an organismic state of readiness to respond in a characteristic way to a stimulus as an object, concept, or situation (Encyclopodiea, 2017). The confidentiality of the participants has been maintained. Other ethical issues like the participants' right to withdrawal, privacy and confidentiality have been regarded well. Their thought about appropriate age of marriage is approximated in number but it is not precise. Rigorous quantitative research is advised for more precise numerical value.The concern was more on opinion, thoughts, beliefs, intention and feelings than on the number.

For analysis of data, the interviews were transcribed. Survey data were already in the written form. They then were coded, categorized and classified into themes. The transcripts were re-read several times. Categories were evaluated several times and reordered. Condensed themes were finally generated. Data saturation guided the stoppage of data collection.

\section{RESULT AND DISCUSSION}

\section{Demographic profiles of participants}

The members of first sample were diverse in age, education and birth by place. Among all, nine were female, seven were male. Two participants were high school dropout, 10 were studying bachelor's degree and four were studying master's degree.

The members of second sample were homogenous by education. 35 participants were surveyed in a class of bachelor's degree. 13 were male and 22 were female. 16 were born in Kathmandu and 19 were born in various 
174 ATTITUDES OF PRESENT GENERATION TOWARDS MARRIAGE ...

districts other than Kathmandu. Two participants were Newar, five were Sherpa, three were Chhetri, four were Gurung, four were Tamang, two were Brahman, one was Magar, one was Thakuri, one was Sanyasi and the rest did not reveal their ethnicity.

\section{Attitude of current generation towards marriage}

Present generation considers marriage as necessary and a positive practice. Some participants said it was not compulsory. Males have more realistic attitude about marriage while female have more emotional attitude towards it. Both genders consider it a great life incident that transforms lifestyle and provides greater responsibility. Males think that marriage is a legal sanction for sexual relationship, a gateway to bearing children and emphasize good planning to take it on. They keep self-reliance as the criterion for marriage. Females think marriage can determine happiness or sadness based on the nature of husband they get. A female participant said that no marriage is better than bad marriage. They said that marriage is a concept that berates women because they have to leave home of birth and go to husbands where their freedom is likelier to be limited and they are soon compelled to bear a child. The findings about attitude are presented in various categories as follows:

\section{Belief about appropriate age of marriage}

It was found that the perceived appropriate age of marriage has shifted upward from around 20 to a range of 25 to 30 in the shift of a generation. The calculation about average age of marriage for parent generation was 20 approximately. For the question, When is the appropriate age of marriage?, participants replied numbers in a range.The parent generation married at around 20; the present generation thinks suitable age of marriage is around 25 for female, and between 25 to 30 for male.A generation has been defined to be a period in which a person grows to be parent of children. It is considered to be 30 years (Oxford Dictionay 2014). From data analysis, following themes are identified.

\section{Thoughts about right age of marriage}

- Minimum career attainment $(n=3)$ :Participants gave a range as right age of marriage, but were flexible in saying that career completion should be the right time to marry. They alluded that the marriage hampers study and career. They mean one can earn enough to support spouse 
and children if oneis self-sufficient. Most of the participants of survey said that they wanted to be capable by completing their study first.

I sometimes think it would not have been this difficult had I married after achievement of life goal. I regret marriage somewhat.” (P15, F)

- No need to marry $(n=2)$ : Some people said it is not very essential to marry in present era. It is because the structure and the way the society functions has drastically changed in present times. Society is slowly shifting to dry capitalism and extreme individualism. Marriage is a contractual and consensual relationship. Some people choose not to join the contract. Some participants said that marriage is a legal sanction for intimate relationship. It is also a social validation of sexual relationship between partners. Some participants said they do not need such validation anymore.

We can choose not to marry also. (P09, M)

\section{Beliefs about why people marry (present generation)}

- Support ( $\mathrm{n}=7$ ): Man (or woman) often feels lonely. He (or she) needs psychological and moral support. When one is in low, he or she needs a shoulder to cry on. Man needs love and family support. Somebody saying "dear, it's alright" is like angels' caressing. It is difficult to live alone. The old age can be disastrous if one is alone. Partners in marriage can be the most trusted financial partners as well. Together, husband and wife can make their economic strength greater and faster. Marriage is done for safe future and accompanied old age.

After you marry, you get a very close friend who you can share virtually everything with that you can not share with everybody- not your relatives, nor your friends. (P07, F)

- Regulation of sex motive $(\mathrm{n}=3)$ : Still hugging and kissing in the public is seen unacceptable socially. For sex, man does not have to marry these days, but for enjoyable and regular sex, it is the best alternative. Nobody takes exception however one has sex with one's spouse (not coercively indeed). Nature wants a balance; man seems to be complement of woman. Participants said that sex is indeed necessary for a healthy life. They also said that marriage regulates the sexual activity of people in society. Marriage prevents sexual anarchy, immoral pregnancy or 
176 ATTITUDES OF PRESENT GENERATION TOWARDS MARRIAGE ...

unwanted births. A participant said that early marriage is a concept introduced in society to regulate sexual activities of teens because they are curious at that age about organs of opposite gender.

(People marry)to fulfill sexual desire. One, it is fulfilled. Two, it doesn't go astray. Imagine the sexual chaos if it's not regulated. (P09, M)

- Pressure ( $\mathrm{n}=4$ ): If one is above 30 and still unmarried, one may have to face social stigma. Girls may be arraigned sterile and boy may be called impotent. Even though $3^{\text {rd }}$ gender is not an outlaw any longer, somebody may be shamed as one if you are a 30-over bachelor. Family pressurizes. Relatives constantly ask, "When are you feeding us banquet, man?"

"Friends are tying the knot these days. Not much, but I feel like 'am I already late'?” (P01, M)

- Company(n=2): Marriage is a compromise. It's very difficult to live alone. To take life ahead, one needs a life partner. She or he is someone whom one can share almost all the things of mind and heart. The life goes pretty easy with somebody one can call his or her own. In a spouse, a man or woman finds a friend, a partner and a comrade. A spouse is a friend forever who is there for help and support no matter what.

Marriage completes a human. Till then he is incomplete. For emotional attachment, I am marrying next year, maybe. (P03, F)

- Race Continuity ( $\mathrm{n}=6$ ): People marry to bear children, have own separate family and settle. Moreover, the race of mankind has to go on. Marriage is a good tradition that keeps a phenomenon of nature up and functioning.

\section{Beliefs about why people married (parent generation)}

- Tradition ( $\mathrm{n}=5$ ): People married as a custom. They took it so obviously. In nobody's mind ever it crossed that anybody could die bachelor too. In wedding, everybody wanted to feast dantebakhro and go to jant. When you go to jant of fifties of relatives and friends there comes a time of reciprocation, too. People married as a result of conformity.

My parents married because you know that's that- they complied with custom. They followed the tradition (P04, M). 
- Family/Settlement (gharjam) (n=3): If they had a spouse, they could go to sasurali /maiti during Dasai as a jwaiorchhori to nod before sasuraba/ sasuaama or father/mother with a flock of bhaza/bhanzi behind them. If someone was a loner, they had no Dasai, no Tihar of that flavor. A married man would not have to worry about old age loneliness.

They married to settle and have a family. (P05, F)

- Parental Order ( $\mathrm{n}=2)$ : Parents understood at $14 / 15$ or onset of puberty, one had intense desire of seeing the genitalia of opposite sex. At 16/17 that desire turned to that of palpating. And at 18/19, one just wanted to do it. Some could not wait that long. Parents arranged for a marriage at the middle of nineteenth. It is the final of teen years. Father gave commands and children could not wait to say, "Yes sir!"

- Race Continuity ( $\mathrm{n}=6)$

Among the unmarried interviewees (of present generation), 50 percent were in relation and the rest were not, but among those in relationship, 40 percent had somebody to get intimate but they did not love to label it a serious relationship. It meant, they would probably not marry the person they had love affairs with.

\section{Evaluation of marriage by present generation}

Overall, most of the participants seemed positive about marriage. They considered it a good tradition as it helped regulate biological necessity and keep the 'law of nature' up and running. There is seen delay of intention in marriage because of changed economic and social circumstances. This is mostly a change of conative attitude towards marriage as compared to parent generation. Cognitive attitude change is not significant whereas the affective attitude change is substantial in present generation as compared to parent generation.

\section{Conative attitude towards marriage}

Conative attitude covers the factors like intention and actions. In the present generation, there were those who said that not marrying is okay. In the parent generation, concept of 'no marriage' was almost null. Most unmarried people of marriageable age in current generation were found to have the intention to marry but they wanted to be 'capable' first. It means the present generation wants to postpone marriage till they are able to take 
on economic burden. Some participants were already married and some among them regretted that they should have been established in career before marrying. Those who regretted were mostly female. Among the unmarried females, some were very suspicious that their career would be hampered after marrying. They doubted that their freedom would remain the same. Parental generation married without delay after they got parental orders or just normatively. Present generation believes that family should not pressurize at all for marriage. The marriage should be done after career attainment and only after somebody is mature enough in all ways. Some participants said that bad marriage is bad as hell and opined that it is better to remain unmarried rather than have a bad marriage. Some participants said that they would marry someone who loved and cared them. It means present generation is very selective about their partner. They emphasize match or compatibility. Unlike the parent generation that adopted partners chosen by parents, this generation is not ready to marry anybody randomly.

\section{Cognitive attitude towards marriage}

Cognitive attitude includes the thoughts and beliefs. Present generation responded that marriage was a good practice. Their thoughts about way of marrying are changing. They showed dissatisfaction about its gaudiness. They believed that marriage should be planned well, a caring, loving and understanding partner is to be tracked down based on the feelings and issues of compatibility, and it should be considered an ordinary practice that endows extraordinary responsibilities. The marriage was taken for granted in parent generation. Present generation is mostly positive about it while a few individuals are indifferent about it.

\section{Affective attitude towards marriage}

Affective attitude is about feelings. Career again is the primary factor for the present generation. Just because they are not economically ready, they are fearful, uncertain and confused about marrying. The emotions of delight and fun are also associated with their thoughts of marriage. The level of emotion of fear associated with marriage has arisen for present generation. Some participants said that marriage is a turning point which means increase in responsibility and change of lifestyle. Change of lifestyle might show for the opportunity for fun and more happiness. The young adults of marriageable age have undue expectations about positive feelings or emotions given by marriage. They expect unlimited love and 
happiness. The expectations about emotions are also a new phenomenon as the love marriages are booming. A few participants could imagine about arranged marriage and intra-caste marriage. Shift of trend from arranged to love marriage is also a shift of less emotional expectation to ideally high emotional expectations. Some participants took marriage for granted. A participant said, "Not marrying is surprising". Some female participants said that marriage aroused sadness and insult because they would have to abandon their home of birth and move like a property and also expressed suspicion that their husbands would restrict their freedom.

The present generation has an overall positive attitude towards marriage. They consider it a good practice to help 'law of nature'. However, indifference towards marriage is on the rise. People seem to want to be economically capable to bear economic and familial burden before they get married. Since it takes time to acquire self-reliance, people have intent of postponing the marriage after 25. The conative attitude is noticeable in delayed intent. The cognitive attitude is perceptible with positive consideration for marriage. Thought about marriage gives emotions of fear and fun and sometimes nervousness in people of present generation. This is the affective attitude of present generation. Present generation wants a perfect compatibility in partner rather than random spouse. Arranged marriage is soon going to be the matter of past. Noticeably there has been an upward shift in perception of suitable age of marriage in a shift of a generation from 20 to a range of 25 to 30 . The reasons are the boom of internet, the education and the independence gotten by the job opportunities. The reasons the present generation marries turned out to be mainly for support including psychological, economical and emotional; pressure from family directly and indirectly e.g. from friend's marrying, for company, and for physical need regulation.

The main attitude change towards marriage is seen when we take a look at reasons why parent generation married and compare them with present reasons. In past, people married for settlement as a social custom and to obey parental orders. They took marriage for granted. They could not even imagine they could live alone or unmarried. Race continuity is the common theme seen on both generations. Interestingly, the romantic love was not the reasons why parents married. Nor does the present generation assert it as the reason for marriage.For present generation, marriage means 
a huge responsibility. They consider self-reliance a criterion for marriage. Marriage is a turning point that puts a person in a position to take leadership of a separate family. The present generation has emotions of fear, confusion and fun connected with marriage. Mostly full-time students were the members of sample chosen conveniently. So, the emotion of fear might have been associated with it. However, it indicates that they believe it to be an economic responsibility to be borne. The female participants' feelings of insult and sadness mean that they consider it a practice of inequality because bride has to abandon her home to go to groom's or his parents' home. It is indicative of rebellion of females for equality in marriage and creation of separate nuclear families after wedlock in coming days.

\section{CONCLUSION}

The huge gap between reasons of marriage of the earlier and the present generation is indicating something bigger. There can be different ramifications of this attitude change in Nepal in the coming days. The birth rate lowers. The modernization may raise the rate of spoilt marriage too. Cohabitation or "living together" may be rampant in the coming decade. The society will see early teenage pregnancies and accepted pre-marital sex. The number of unmarried women may increase. The households with single parent may go up.The government should be prepared timely to address these challenges. The businessmen, but, may see some lucrative prospects of these changes. In Nepal, very few researches have been conducted from psychological perspectives. The following researches may have quantitative approach to look at attitude of people towards marriage or its change. Changing marriage attitude may have other dimensions like divorce, extramarital affairs, still prevailing child marriage, changed anomalies of dowry in modern times, paper/dramatic marriage to get visas in developed nations, pre-marital sex, teenage pregnancy, polygamy, children out of marriage, marital rape, marriage gala and wedding extravagance, and so on. With psychological focus, each can be researched qualitatively. In Nepalese society, psychological research has barely touched these areas.

The research participants were mostly from urban area or were from rural area but living in cities for years. Hence, the limitation is that the study might lack healthy rural perspective. The sample was dominated by educated participants. Since, the research is qualitative; it might not be 
totally generalizable. The findings of this qualitative research are explorative. Hence, there exist no researches conducted in past for comparison.

\section{WORKS CITED}

Ahearn, L. M. (2002). Invitations to love: literacy, love letters, and social change in Nepal. Ann Arbor: University of Michigan.

Ahmad, S., \& Reid, D. W. (2008). Relationship satisfaction among South Asian Canadians: The role of 'complementary-equality' and listening touderstand. Interpersona, 2(2), pp. 131-150.

Amatya,S.(2005).GenderandHIV/AIDSinNepal:someobservations.Indian Anthropologist, 35(1/2), pp. 139-152. doi: 10.2307/41919984

Aryal, T. R. (2007). Age at first marriage in Nepal: differentials and determinants. J Biosoc Sci. , 39(5), pp. 693-706.

- - - (2011). Age at menarche and its relation to ages at marriage, first-birth and menopause among rural nepalese females. Nepal Journal of Science and Technology, (12), pp. 276-285.

Baunach, D. M. (2011). Decomposing trends in attitudes toward gay marriage, 1988-2006n. Social Science Quarterly 92(2).

Chalaune, P. (2009). Water, wealth and power:A case study from upper Mustang of Nepal. Occasional Papers in Sociology and Anthropology, (11), pp. 104-125.

Choe, M. K., Westley, S. B., \& Retherford, R. D. (2002). The future of population in Asia: tradition and change in marriage and family life. Journal of Family Planning.

Coltabiano, M., \& Castiglioni, M. (2008). Changing family formation in nepal: Marriage, cohabitation and first sexual intercourse. International family planning perspectives. 34(1), pp. 30-39.

Doskoch, P. (2013). Child marriage associated with suboptimal reproductive health. International perspectives on sexual and reproductive health, Nepal. Journal of Science and Techonology 39(2), pp. 105-106.

Duberman, L., \& Azumi, K. (1975). Sexism in Nepal. Journal of Marriage and Family, 37(4), pp. 1013-1021. 
Encyclopedia Britannica (2015). Marriage. Retrieved August 2, 2017, from https:// www.britannica.com/topic/marriage

- - - (2017). Marriage. Retrieved August 1,2017, from https://www.merriamwebster.com/dictionary/marriage

Freedman, A. T. (1982). Changing attitudes toward marriage and single life. Journal of Family Planning, 14(6), pp. 297-303.

Fricke, T., Arland, T., \& Dahal, D. R. (1998). Netting in Nepal: Social change, the life course, and brideservice in Sangila. Human Ecology, 26(2), pp. 213-237. doi: 10.2307/4603278

Gubernskaya, Z. (2010). Changing attitudes toward marriage and children in six countries. Sociological Perspectives, 53(2), pp. 179-200.

Gurung, J. B. (2012). Rapid cultural change: A case study of polyandry marriage system among the gurung community from upper Mustang, Nepal. DhaulagiriJournalof Sociology and Anthropology, (6), pp. 75-106.

Higgins, L. T., Zheng, M., Liu, Y., \& Sun, C. H. (2002). Attitudes to marriage and sexual behaviors: A survey of gender and culture differences in China and United Kingdom. Journal of Family Planning, 46(3/4).

Jones, G. W. (2003). The flight from marriage. Asian Metacenter Research Paper Series, (11). South-East and East Asia.

- - (2012). Late marriage and low fertility in Singapore: The limits of policy. The Japanese Journal of Population, 10(1).

Kirkpatrick, C. (1936). Student attitudes toward marriage and sex. Journal of Educational Sociology, 9(9), pp. 545-555.

Lee, S. T. (2012). Beautifully imperfect: Using facebook to change a population's attitudes toward marriage. Public Relations Review, (38), pp. 515-517.

Matsumoto, D. (Ed.) (2009). The cambridge dictionary of psychology. Tokyo: Cambridge University Press.

Mishra, M. (2012). Women's access to education in Nepal: Intergenerational change. Dhaulagiri Journal of Sociology and Anthropology, (9), pp. 49-60. 
Niraula, B. B., \& Morgan, S. P. (1996). Marriage formation, post-marital contact with natal kin and autonomy of women: evidence from two nepali settings. Population Studies, 50(1), pp. 35-50. doi: $10.2307 / 2175029$

Oxford Dictionary (2014). Oxford: Oxford University Press.

Podmore, D., \& Chaney, D. (1972). Attitudes towards marriage and the family amongst young people in Hong Kong, and comparisons with the United States and Taiwan. Journal of Comparative Family Studies, 3(2), pp. 228-238.

Prindle, P. H. (1978). Marriage by exchange in East Nepal. Anthropos, 73(1/.2), pp. 133-140.

Sah, N. (2008). How useful are the demographic surveys in explaining the determinants of early marriage of girls in the Terai of Nepal? Journal of Population Research, 25(2).

Seligman, M. E. P. (2004). Authentic happiness:Using the new positive psychology to realize your potential for lasting fulfillment. Atria Books.

Shrestha, K. K. (2009). Ethnography of Jhapali Rajbanshis. Occasional Papers in Sociology and Anthropology, 11, pp. 38-47.

Shreth, A. (1987). A study of wedding ritual popular among Tharu people in Bara district (in Nepali). An unpublished thesis submitted to Central Department of Sociology. Birgunj: TU.

Skolnick, A. (2008). Marriage. Microsoft Student 2009 [DVD]. Redmond, WA: Microsoft Corporation.

Tashakori, A., \& Thompson, V. D. (1988). Cultural change and attitude change: An assessment of postrevolutionary marriage and family attitudes in Iran. Population Research and Policy Review, 3(27).

Thapa, S., \& Padhye, S. M. (2001). Induced abortion in urban Nepal. International Family Planning Perspectives, 27(3), pp. 144-151. doi: $10.2307 / 2673836$

Thapa, S., \& Retherford, R. D. (1976). Infant mortality estimates based on the 1976 Nepal fertility survey. Population Studies, 36(1), Kathmandu: pp. 61-80. 
184 ATTITUDES OF PRESENT GENERATION TOWARDS MARRIAGE ...

The Economist (2011). Flight from marriage. Retrieved December 25, 2014, from www.economist.com/node/21526329.

Tuladhar, R. (1998). Effect of women's education, occupation and age at marriage on fertility in Kathmandu Municipality. An unpublished thesis submitted to Central Department of Sociology. Kathmandu: TU.

Yabiku, S. T. (2004). Marriage timing in Nepal: organizational effects and individual mechanisms. Social Forces, 83(2), pp. 559-586. doi: $10.2307 / 3598340$. 